\title{
Pseudokineococcus lusitanus gen. nov., sp. nov., and reclassification of Kineococcus marinus Lee 2006 as Pseudokineococcus marinus comb. nov.
}

\author{
Valme Jurado, ${ }^{1}$ Leonila Laiz, ${ }^{1}$ Alberto Ortiz-Martinez, ${ }^{1}$ Ingrid Groth ${ }^{2}$ \\ and Cesareo Saiz-Jimenez ${ }^{1}$ \\ ${ }^{1}$ Instituto de Recursos Naturales y Agrobiologia, CSIC, Apartado 1052, 41080 Sevilla, Spain \\ ${ }^{2}$ Hans-Knöll-Institut für Naturstoff-Forschung e. V., D-07745 Jena, Germany
}

Correspondence

Valme Jurado

vjurado@irnase.csic.es

\begin{abstract}
A Gram-reaction-positive, motile, coccus-shaped actinobacterium, designated strain T2A-S27 ${ }^{\top}$, was isolated from a roof tile in Oporto (Portugal) and studied using a polyphasic approach. The 16S rRNA gene sequence of the novel isolate showed high similarity to that of Kineococcus marinus KST3-3 $3^{\top}$ (97.8\% sequence similarity). Strain T2A-S $27^{\top}$ showed lower $16 \mathrm{~S}$ rRNA gene sequence similarities with other members of the genus Kineococcus and members of the family Kineosporiaceae ( $<94 \%)$. A phylogenetic tree, based on $16 \mathrm{~S}$ rRNA gene sequences, showed that strain $\mathrm{T} 2 \mathrm{~A}-\mathrm{S} 2 \mathrm{7}^{\mathrm{T}}$ formed a coherent clade with the type strain of $K$. marinus and Quadrisphaera granulorum. The isolate was characterized by the presence of meso-diaminopimelic acid in the cell-wall peptidoglycan, MK- $9\left(\mathrm{H}_{2}\right)$ as the predominant menaquinone and a polar lipid profile consisting of diphosphatidylglycerol and phosphatidylglycerol. The fatty acid profile was dominated by anteiso- $\mathrm{C}_{15}$ :0. The DNA G+C content was 76.9 mol\%. The low level of DNA-DNA relatedness to $K$. marinus (46-47\%) and the results of the chemotaxonomic and physiological studies clearly distinguished strain T2A-S27 ${ }^{\top}$ from recognized species of the genus Kineococcus. On the basis of its phylogenetic position and phenotypic traits, strain T2A-S27 $7^{\top}\left(=\right.$ LMG $24148^{\top}=$ CECT $7306^{\top}=$ DSM $23768^{\top}$ ) represents a novel species of a new genus in the family Kineosporiaceae, for which the name Pseudokineococcus lusitanus gen. nov., sp. nov. is proposed. The misclassified species K. marinus is transferred to the new genus as Pseudokineococcus marinus comb. nov. The type strain of Pseudokineococcus marinus is KST3-3 ${ }^{\top}\left(=\right.$ KCCM $42250^{\top}=$ NRRL B-24439 $\left.{ }^{\top}\right)$.
\end{abstract}

Recently, the new suborder Kineosporiineae and the valid family Kineosporiacae have been described by Zhi et al. (2009). At the time of writing, the family Kineosporiaceae included the genera Angustibacter (Tamura et al., 2010), Kineococcus (Yokota et al., 1993), Kineosporia (Pagani \& Parenti, 1978) and Quadrisphaera (Maszenan et al., 2005).

In a survey on the colonization of roof tiles in Oporto, Portugal, a Kineococcus-like strain, designated $\mathrm{T} 2 \mathrm{~A}-\mathrm{S} 27^{\mathrm{T}}$, was isolated from a grey biofilm covering a roof tile, together with strains that were assigned to the genera Streptomyces, Microbacterium, Pseudomonas, Azospirillum and Cellulomonas. The aim of the present study was to determine the taxonomic position of strain $\mathrm{T} 2 \mathrm{~A}-\mathrm{S} 27^{\mathrm{T}}$. On the basis of the results presented below, the isolate represents a novel species of a new genus within the family

The GenBank/EMBL/DDBJ accession number for the 16S rRNA gene sequence of strain T2A-S27 ${ }^{\top}$ is FN824365.

One supplementary table is available with the online version of this paper.
Kineosporiaceae, which also incorporates the misclassified species Kineococcus marinus.

Strain T2A-S27 ${ }^{\mathrm{T}}$ was isolated on Tryptose Soy Agar (TSA) (Oxoid) after 4 weeks at $28{ }^{\circ} \mathrm{C}$. The methods used in this study have been described previously (Jurado et al., 2005a, b) except where indicated otherwise. Briefly, wet slide suspensions of cultures grown in TSA were observed by phase-contrast microscopy. Acid production from a variety of substrates was tested using the API $50 \mathrm{CH}$ B/E kit (bioMérieux) and assimilation tests were carried out using the API 20 NE kit (bioMérieux); API tests were performed according to the manufacturer's instructions. Susceptibility to antibiotics was studied by placing antibiotic discs (Mast Diagnostics) on TSA plates inoculated with suspensions of the test strains. Oxidase activity was studied by monitoring oxidation on DrySlide oxidase (Becton Dickinson). For the Gram reaction, a $3 \%$ solution of potassium hydroxide was used (Halebian et al., 1981). Flagella were stained with flagella stain droppers (Becton Dickinson). Growth was determined at $4-40{ }^{\circ} \mathrm{C}$. Tolerance to $\mathrm{NaCl}$ was studied on 
TSA and in nutrient broth supplemented with $0-10 \%$ $(\mathrm{w} / \mathrm{v}) \mathrm{NaCl}$. Cellular fatty acids were determined as described previously (Jurado et al., 2009). The polar lipid profile, whole-cell sugars and $\mathrm{G}+\mathrm{C}$ content of the genomic DNA were determined at the DSMZ. For phylogenetic analysis, the almost complete 16S rRNA gene sequence of strain $\mathrm{T} 2 \mathrm{~A}-\mathrm{S} 27^{\mathrm{T}}$ was aligned and compared with the corresponding sequences of members of the family Kineosporiaceae and other representatives of taxa of the order Actinomycetales using the multiple sequence alignment program CLUSTAL_X (Thompson et al., 1997). Phylogenetic and molecular evolutionary analyses were conducted using MEGA version 4 (Tamura et al., 2007) and PHYLO_WIN (Galtier et al., 1996) with three treeing algorithms, the maximum-likelihood (Felsenstein, 1981), maximum-parsimony (Kluge \& Farris, 1969) and neighbour-joining (Saitou \& Nei, 1987) methods. The robustness of the resultant tree was assessed by bootstrap resampling (1000 replicates each). The degree of genomic relatedness between strain $\mathrm{T} 2 \mathrm{~A}-\mathrm{S} 27^{\mathrm{T}}$ and Kineococcus marinus KCCM $42250^{\mathrm{T}}$ (the most closely related species on the basis of 16S rRNA gene sequence similarity) was determined by DNA-DNA hybridization, as described by De Ley et al. (1970) and Rosselló-Mora \& Amann (2001).

Cells of strain $\mathrm{T} 2 \mathrm{~A}-\mathrm{S} 27^{\mathrm{T}}$ were aerobic, non-spore-forming, Gram-reaction-positive cocci that occurred singly or in pairs, tetrads and clusters and were motile due to flagella. Strain T2A-S $27^{\mathrm{T}}$ was oxidase-negative and catalase-positive. Other physiological characteristics of strain $\mathrm{T} 2 \mathrm{~A}-\mathrm{S} 27^{\mathrm{T}}$ are shown in Table 1.

Analysis of $16 \mathrm{~S}$ rRNA gene sequences revealed that strain T2A-S27 ${ }^{\mathrm{T}}$ formed a distinct cluster together with K. marinus ( $97.8 \%$ sequence similarity, corresponding to $31 \mathrm{nt}$ differences among $1381 \mathrm{nt}$ positions) in the phylogenetic gene tree of the class Actinobacteria. Strain T2A-S2 $7^{\mathrm{T}}$ was loosely related to Quadrisphaera granulorum ( $93.8 \%$ sequence similarity), from which it could be readily distinguished by the menaquinone type of $\mathrm{MK} 8\left(\mathrm{H}_{2}\right)$ and further phenotypic characteristics (Table 1). The 16S rRNA gene sequence similarities between strain $\mathrm{T} 2 \mathrm{~A}-\mathrm{S} 27^{\mathrm{T}}$ and all species of the genus Kineococcus (except K. marinus) were < $<4 \%$ (93.0\% for Kineococcus aurantiacus, $93.0 \%$ for Kineococcus radiotolerans, $92.5 \%$ for Kineococcus gynurae, $93.5 \%$ for Kineococcus xinjiangensis and $93.2 \%$ for Kineococcus rhizosphaerae). The $16 \mathrm{~S}$ rRNA gene phylogenetic tree showed that the strain T2A-S27 $-K$. marinus-Q. granulorum cluster obtained using the neighbour-joining, maximum-likelihood and maximum-parsimony treeing algorithms was supported by a bootstrap value of $76 \%$, showing that strain $\mathrm{T} 2 \mathrm{~A}-\mathrm{S} 27^{\mathrm{T}}$ and $K$. marinus were phylogenetically distinct from the genus Kineococcus (Fig. 1). Furthermore, strain T2A-S27 ${ }^{\mathrm{T}}$ exhibited chemotaxonomic differences from all species of the genus Kineococcus and Q. granulorum (Table 2). The $16 \mathrm{~S}$ rRNA gene nucleotide signature pattern was typical of the suborder described by Zhi et al. (2009), although strain $\mathrm{T} 2 \mathrm{~A}-\mathrm{S} 27^{\mathrm{T}}$ and $K$. marinus shared the same pattern of $16 \mathrm{~S}$ rRNA signature nucleotides at positions $75(\mathrm{G})$,
Table 1. Phenotypic characteristics of strain $\mathrm{T} 2 \mathrm{~A}-\mathrm{S} 27^{\top}$ and related species

Strains: 1 , T2A-S27 $; 2$, K. marinus KCCM $42250^{\mathrm{T}} ; 3$, K. aurantiacus IFO $15268^{\mathrm{T}} ; 4$, K. radiotolerans ATCC BAA- $149^{\mathrm{T}} ; 5$, K. gynurae NRRL B-24568 ${ }^{\mathrm{T}} ; 6$, K. xinjiangensis CCTCC АВ $207179^{\mathrm{T}}$; 7 , K. rhizosphaerae DSM $19711^{\mathrm{T}} ; 8$, Q. granulorum DSM $44889^{\mathrm{T}}$. For phenotypic tests, strain $\mathrm{T} 2 \mathrm{~A}-\mathrm{S} 2 \mathrm{7}^{\mathrm{T}}$ and $K$. marinus were grown under the same conditions in this study. Data for the reference strains $K$. aurantiacus, K. radiotolerans, K. gynurae, K. xinjiangensis, K. rhizosphaerae and Q. granulorum were taken from Lee (2009), Duangmal et al. (2008), Liu et al. (2009) and Maszenan et al. (2005). +, positive; -, negative; $(+)$ weakly positive; $+/-$, variable; ND, not determined.

\begin{tabular}{|c|c|c|c|c|c|c|c|c|}
\hline Characteristic & 1 & 2 & 3 & 4 & 5 & 6 & 7 & 8 \\
\hline \multicolumn{9}{|l|}{ Acid produced from: } \\
\hline D-Arabitol & - & + & ND & ND & + & ND & ND & + \\
\hline D-Galactose & + & + & - & + & + & ND & + & - \\
\hline Lactose & $(+)$ & + & - & - & + & ND & - & - \\
\hline Maltose & + & + & - & - & + & + & + & - \\
\hline D-Mannitol & + & + & - & + & + & - & $\mathrm{ND}$ & - \\
\hline D-Mannose & + & + & - & + & + & $\mathrm{ND}$ & + & - \\
\hline Melezitose & - & + & ND & $\mathrm{ND}$ & + & $\mathrm{ND}$ & + & - \\
\hline Melibiose & $+1-$ & - & ND & $\mathrm{ND}$ & + & ND & + & ND \\
\hline Raffinose & - & + & - & - & - & ND & + & - \\
\hline D-Ribose & - & + & - & - & - & - & - & ND \\
\hline Trehalose & + & + & - & ND & + & ND & - & ND \\
\hline Gentiobiose & - & + & ND & $\mathrm{ND}$ & + & ND & ND & ND \\
\hline Glycerol & + & + & - & + & - & ND & - & + \\
\hline Inositol & - & $(+)$ & - & + & - & + & $\mathrm{ND}$ & ND \\
\hline L-Rhamnose & + & + & - & - & + & + & - & - \\
\hline $\mathrm{N}$-Acetylglucosamine & $+1-$ & - & $\mathrm{ND}$ & ND & - & ND & ND & - \\
\hline \multicolumn{9}{|l|}{ Growth at/in: } \\
\hline $7 \%(\mathrm{w} / \mathrm{v}) \mathrm{NaCl}$ & $(+)$ & + & - & - & $(+)$ & - & - & ND \\
\hline $5{ }^{\circ} \mathrm{C}$ & - & + & - & - & - & - & - & - \\
\hline \multicolumn{9}{|l|}{ Hydrolysis of: } \\
\hline Aesculin & + & + & - & $\mathrm{ND}$ & ND & + & + & + \\
\hline Gelatin & + & + & - & $\mathrm{ND}$ & + & + & + & - \\
\hline Starch & $\mathrm{v}$ & + & - & - & ND & - & - & ND \\
\hline Urea & - & - & + & - & + & - & + & - \\
\hline
\end{tabular}

$79(\mathrm{G}), 139(\mathrm{C}), 191(\mathrm{U}), 203(\mathrm{G}), 381(\mathrm{G}), 589(\mathrm{C}), 591(\mathrm{C})$, $610(\mathrm{G}), 630(\mathrm{~T}), 648(\mathrm{G}), 837(\mathrm{U}), 839(\mathrm{G}), 849(\mathrm{G}), 1010$ $(\mathrm{U}), 1020(\mathrm{U}), 1121(\mathrm{G}), 1152(\mathrm{C})$ and $1252(\mathrm{U})$ based on the numbering system of the Escherichia coli 16S rRNA gene sequence (GenBank accession number J01695). Thus, based on phylogenetic and chemotaxonomic data, strain $\mathrm{T} 2 \mathrm{~A}-\mathrm{S} 27^{\mathrm{T}}$ did not belong to the genera Kineococcus or Quadrisphaera. The high sequence similarity between strain $\mathrm{T} 2 \mathrm{~A}-\mathrm{S} 27^{\mathrm{T}}$ and $K$. marinus suggested that they belong to the same genus.

Although strain $\mathrm{T} 2 \mathrm{~A}-\mathrm{S} 27^{\mathrm{T}}$ was most closely related to $K$. marinus, both organisms showed numerous differences in their physiological and chemotaxonomic characteristics (Tables 1 and 2). In addition to the differences presented in Table 1, strain $\mathrm{T} 2 \mathrm{~A}-\mathrm{S} 27^{\mathrm{T}}$ was positive for acid production from L-sorbose, while K. marinus was negative for this trait; 


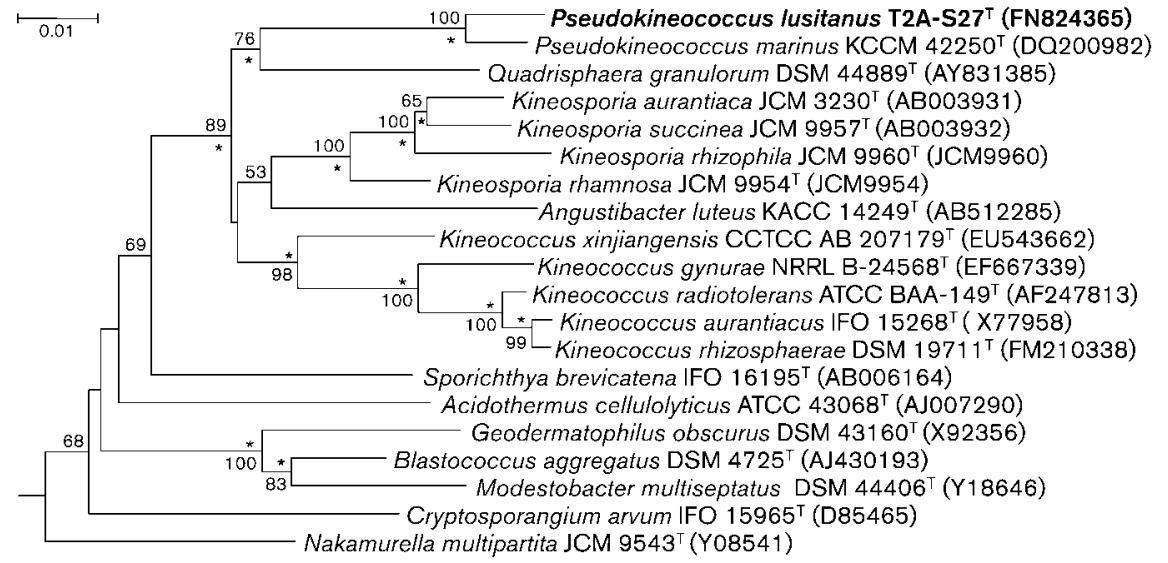

Fig. 1. Phylogenetic tree, based on $16 \mathrm{~S}$ rRNA gene sequences, showing the relationships between strain $\mathrm{T}_{2} \mathrm{~A}-\mathrm{S} 27^{\top}$ and species belonging to the suborders Frankineae and Kineosporiineae. The tree was reconstructed by using the neighbourjoining method and was based on a comparison of 1407 nt. The tree was rooted by using Mycobacterium alvei DSM $44176^{\top}$ (accession no. AF023664) as the outgroup (not shown). Bootstrap values are expressed as percentages of 1000 replications. Asterisks indicate branches of the tree that were also recovered using maximum-likelihood and maximum-parsimony treeing algorithms. Bar, 0.01 substitutions per nucleotide position.

the opposite was seen for D-adonitol. Also, strain T2A-S27 ${ }^{\mathrm{T}}$ produced alkaline phosphatase, acid phosphatase and $N$-acetyl- $\beta$-glucosaminidase unlike $K$. marinus which produced $\alpha$-galactosidase. While $K$. marinus assimilated mannose, potassium gluconate and DL-malic acid, strain T2A-S27 $7^{\mathrm{T}}$ did not. Strain T2A-S27 ${ }^{\mathrm{T}}$ grew well on TSA at concentrations of $\mathrm{NaCl}$ below $8 \%(\mathrm{w} / \mathrm{v})$ with an optimum at $0-3 \%(\mathrm{w} / \mathrm{v})$, while $K$. marinus tolerated up to $9 \%(\mathrm{w} / \mathrm{v})$ $\mathrm{NaCl}$ with optimal growth at $1-4 \%(\mathrm{w} / \mathrm{v})$. Growth of strain
T2A-S27 ${ }^{\mathrm{T}}$ occurred at $6-37{ }^{\circ} \mathrm{C}$ with an optimum at $28-$ $30{ }^{\circ} \mathrm{C}$, while the temperature range for growth of $\mathrm{K}$. marinus was $4-37{ }^{\circ} \mathrm{C}$. Strain T2A-S $27^{\mathrm{T}}$ contained glucose, ribose and rhamnose as characteristic sugars in the whole-cell hydrolysates, while arabinose and galactose were found in $K$. marinus. Further differences were noticed in the compositions of polar lipids and fatty acids. Diphosphatidylglycerol was the main polar lipid in strain T2A-S2 ${ }^{\mathrm{T}}$, which was absent in $K$. marinus. Phosphatidylinositol was present

Table 2. Phenotypic characteristics of strain $\mathrm{T} 2 \mathrm{~A}-\mathrm{S} 27^{\mathrm{T}}$ and related taxa

Data from Tamura et al. (2010), Lee (2006) and this study. $\mathrm{A}_{2} \mathrm{pm}$, diaminopimelic acid; A, anteiso-methyl-branched; I, iso-methyl-branched; M, 9- 10-methyl-branched; S, straight-chain saturated; U, monounsaturated; DPG, diphosphatidylglycerol; GL, unknown glycolipid; PC, phosphatidylcholine; PG, phosphatidylglycerol; PI, phosphatidylinositol; PIM, phosphatidylinositol mannosides; PL, unknown phospholipids; PGL, unknown phosphoglycolipid; Ara, arabinose; Gal, galactose; Glu, glucose; Man, mannose; Rha, rhamnose; Rib, ribose; ND, no data.

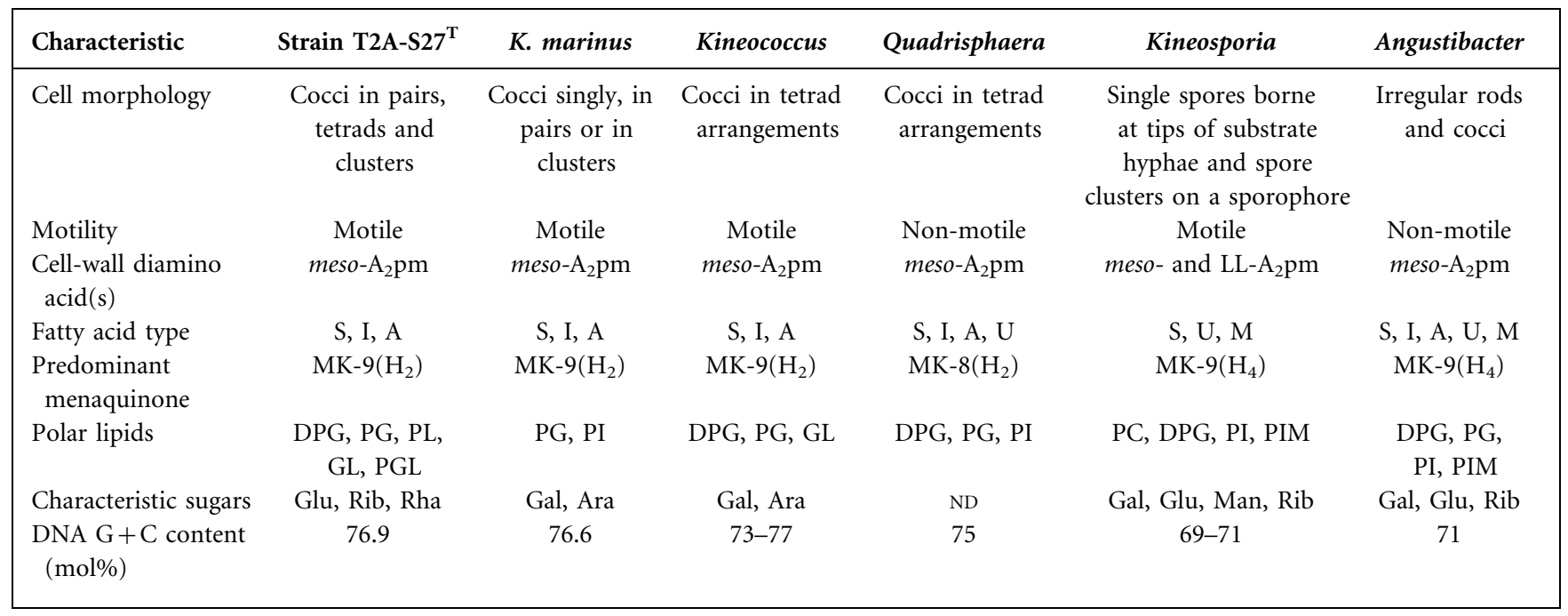


only in K. marinus. In both species anteiso- $\mathrm{C}_{15: 0}$, was the predominant fatty acid, which is a typical characteristic of the genus Kineococcus (Yokota et al., 1993); however, there were differences in the pattern of other fatty acids between strain T2A-S27 $7^{\mathrm{T}}$ and K. marinus as shown in the Supplementary Table S1 (available in IJSEM Online).

The DNA G + C content of strain T2A-S27 ${ }^{\mathrm{T}}$ was $76.9 \mathrm{~mol} \%$. The level of DNA-DNA relatedness between strain T2A$\mathrm{S} 27^{\mathrm{T}}$ and $\mathrm{K}$. marinus KCCM $42250^{\mathrm{T}}$ was $46.6 \pm 0.8$.

The phenotypic and genotypic characteristics described above and the observed differences between strain T2A-S27 $7^{\mathrm{T}}$ and previously described species of the genus Kineococcus revealed that strain T2A-S2 $7^{\mathrm{T}}$ represents a novel species of a new genus, for which the name Pseudokineococcus lusitanus gen. nov., sp. nov., is proposed. K. marinus is transferred to the new genus as Pseudokineococcus marinus comb. nov.

\section{Description of Pseudokineococcus gen. nov.}

Pseudokineococcus (Pseu.do.ki.ne.o.coc'cus. Gr. adj. pseudês false; NL. masc. n. kineococcus a bacterial genus name; N.L. masc. n. Pseudokineococcus the false Kineococcus).

Cells are spherical, $1.0-1.5 \mu \mathrm{m}$ in diameter and occur in pairs, in tetrads, or in clusters. Cells are motile and have tufts of flagella. Endospores are not formed. Gram-positive. Colonies are circular, rough and orange-coloured. Strictly aerobic. Catalase-positive and oxidase-negative. Do not reduce nitrate to nitrite. Acid is produced from glucose and some other sugars. Aesculin is hydrolysed. The diagnostic diamino acid of the peptidoglycan is meso-diaminopimelic acid. The major menaquinone is MK-9 $\left(\mathrm{H}_{2}\right)$. Mycolic acids are not present. The characteristic phospholipid of the genus is phosphatidylglycerol. Diphosphatidylglycerol and phosphatidylinositol may be present. The major cellular fatty acid is anteiso- $C_{15: 0}$. The type species of the genus is Pseudokineococcus lusitanus.

\section{Description of Pseudokineococcus lusitanus sp. nov.}

Pseudokineococcus lusitanus (lu.si.ta'nus. L. masc. adj. belonging to Lusitania the Latin name for Portugal, where the organism was isolated).

Cells are Gram-reaction-positive cocci that are $1.0-1.5 \mu \mathrm{m}$ in diameter and occur singly or in pairs, tetrads or clusters. Colonies are circular, rough and orange-coloured. Cells are aerobic, oxidase-negative, urease-negative and catalase-positive. Growth occurs at $6-37{ }^{\circ} \mathrm{C}$ (optimum $28-30{ }^{\circ} \mathrm{C}$ ). Grows well at $0-3 \%(\mathrm{w} / \mathrm{v}) \mathrm{NaCl}$, moderately at $5-6 \%$ and poorly at 7-8\%. Produces acid from D-and L-arabinose, D-xylose, D-glucose, D-fructose, L-sorbose, D-sorbitol, methyl- $\alpha$-Dglucopyranoside, amygdalin, arbutin, aesculin, salicin, cellobiose, sucrose, starch, glycogen, xylitol, turanose and D-lyxose but not from erythritol, L-xylose, D-adonitol, methyl- $\beta$-Dxylopyranoside, dulcitol, methyl- $\alpha$-D-mannopyranoside, inulin, L-arabitol, D-fucose, potassium gluconate, 2-ketogluconate, 5-ketogluconate or L-fucose. Acid production from Dtagatose is variable. Produces alkaline phosphatase, esterase (C1), esterase lipase (C8), leucine arylamidase, trypsin, acid phosphatase, naphthol-AS-BI-phosphohydrolase, $\beta$-galactosidase, $\alpha$ - and $\beta$-glucosidase, $N$-acetyl- $\beta$-glucosaminidase and $\alpha$-mannosidase but not lipase (C14), valine arylamidase, cystine arylamidase, $\alpha$-chymotrypsin, $\alpha$-galactosidase, $\beta$ glucuronidase or $\alpha$-fucosidase. Assimilates glucose, Larabinose, mannitol, $\mathrm{N}$-acetylglucosamine and maltose but does not assimilate mannose, gluconate, capric acid, adipic acid, DL-malic acid, citrate or phenylacetic acid. Negative for glucose fermentation and arginine dihydrolase activities. Nitrate reduction and indole tests are negative. Sensitive to ( $\mu$ g per disc) chloramphenicol (30), rifampicin (5), tetracycline (30), novobiocin (30), streptomycin (10), carbenicillin (100), framycetin (50), erythromycin (15), doxycycline (30), vancomycin (30), gentamicin (10) and kanamycin (30) but resistant to norfloxacin (10), ampicillin (10) and nalidixic acid (30). The predominant fatty acid is anteiso$\mathrm{C}_{15: 0}$. Whole-cell hydrolysates contain glucose, ribose, rhamnose and traces of galactose, mannose and xylose. The major menaquinone is MK-9 $\left(\mathrm{H}_{2}\right)$. Polar lipids comprise diphosphatidylglycerol, phosphatidylglycerol, an unidentified phospholipid, an unidentified glycolipid and an unidentified phosphoglycolipid.

The type strain, T2A-S27 ${ }^{\mathrm{T}}\left(=\mathrm{LMG} 24148^{\mathrm{T}}=\mathrm{CECT} 7306^{\mathrm{T}}\right.$ $=$ DSM $23768^{\mathrm{T}}$ ) was isolated from a roof tile in Oporto, Portugal. The DNA G+C content of the type strain is $76.9 \mathrm{~mol} \%$.

\section{Description of Pseudokineococcus marinus comb. nov.}

Pseudokineococcus marinus (ma.ri'nus. L. masc. adj. marinus of the sea, the origin of the sample from which the type strain was isolated).

Basonym: Kineococcus marinus Lee (2006).

The description is identical to that given for Kineococcus marinus by Lee (2006). The type strain is KST3-3 ${ }^{\mathrm{T}}$ $\left(=\right.$ KCCM $42250^{\mathrm{T}}=$ NRRL B-24439 $)$.

\section{Acknowledgements}

Funding from Consolider project TCP CSD2007-00058 is acknowledged. Polar lipid analyses were carried out by Dr B.J. Tindall, DSMZ, Braunschweig, Germany.

\section{References}

De Ley, J., Cattoir, H. \& Reynaerts, A. (1970). The quantitative measurement of DNA hybridization from renaturation rates. Eur $J$ Biochem 12, 133-142.

Duangmal, K., Thamchaipenet, A., Ara, I., Matsumoto, A. \& Takahashi, Y. (2008). Kineococcus gynurae sp. nov., isolated from a Thai medicinal plant. Int J Syst Evol Microbiol 58, 2439-2442. 
Felsenstein, J. (1981). Evolutionary trees from DNA sequences: a maximum likelihood approach. J Mol Evol 17, 368-376.

Galtier, N., Gouy, M. \& Gautier, C. (1996). SEAVIEW and PHYLO_WIN: two graphic tools for sequence alignment and molecular phylogeny. Comput Appl Biosci 12, 543-548.

Halebian, S., Harris, B., Finegold, S. M. \& Rolfe, R. D. (1981). Rapid method that aids in distinguishing Gram-positive from Gramnegative anaerobic bacteria. J Clin Microbiol 13, 444-448.

Jurado, V., Groth, I., Gonzalez, J. M., Laiz, L. \& Saiz-Jimenez, C. (2005a). Agromyces salentinus sp. nov. and Agromyces neolithicus sp. nov. Int J Syst Evol Microbiol 55, 153-157.

Jurado, V., Laiz, L., Gonzalez, J. M., Hernandez-Marine, M., Valens, M. \& Saiz-Jimenez, C. (2005b). Phyllobacterium catacumbae sp. nov., a member of the order 'Rhizobiales' isolated from Roman catacombs. Int J Syst Evol Microbiol 55, 1487-1490.

Jurado, V., Kroppenstedt, R. M., Saiz-Jimenez, C., Klenk, H.-P., Mouniée, D., Laiz, L., Couble, A., Pötter, G., Boiron, P. \& RodríguezNava, V. (2009). Hoyosella altamirensis gen. nov., sp. nov., a new member of the order Actinomycetales isolated from a cave biofilm. Int J Syst Evol Microbiol 59, 3105-3110.

Kluge, A. G. \& Farris, F. S. (1969). Quantitative phyletics and the evolution of anurans. Syst Zool 18, 1-32.

Lee, S. D. (2006). Kineococcus marinus sp. nov., isolated from marine sediment of the coast of Jeju, Korea. Int J Syst Evol Microbiol 56, 1279-1283.

Lee, S. D. (2009). Kineococcus rhizosphaerae sp. nov., isolated from rhizosphere soil. Int J Syst Evol Microbiol 59, 2204-2207.

Liu, M., Peng, F., Wang, Y., Zhang, K., Chen, G. \& Fang, C. (2009). Kineococcus xinjiangensis sp. nov., isolated from desert sand. Int J Syst Evol Microbiol 59, 1090-1093.
Maszenan, A. M., Tay, J.-H., Schumann, P., Jiang, H. L. \& Tay, S. T. (2005). Quadrisphaera granulorum gen. nov., sp. nov., a Grampositive polyphosphate-accumulating coccus in tetrads or aggregates isolated from aerobic granules. Int J Syst Evol Microbiol 55, 17711777.

Pagani, H. \& Parenti, F. (1978). Kineosporia, a new genus of the order Actinomycetales. Int J Syst Evol Microbiol 28, 401-406.

Rosselló-Mora, R. \& Amann, R. (2001). The species concept for prokaryotes. FEMS Microbiol Rev 25, 39-67.

Saitou, N. \& Nei, M. (1987). The neighbor-joining method: a new method for reconstructing phylogenetic trees. Mol Biol Evol 4, 406425.

Tamura, K., Dudley, J., Nei, M. \& Kumar, S. (2007). MEGA4: molecular evolutionary genetics analysis (MEGA) software version 4.0. Mol Biol Evol 24, 1596-1599.

Tamura, T., Ishida, Y., Otoguro, M., Yamamura, H., Hayakawa, M. \& Suzuki, K.-I. (2010). Angustibacter luteus gen. nov., sp. nov., isolated from subarctic forest soil. Int J Syst Evol Microbiol 60, 2441-2445.

Thompson, J. D., Gibson, T. J., Plewniak, F., Jeanmougin, F. \& Higgins, D. G. (1997). The CLUSTAL_X windows interface: flexible strategies for multiple sequence alignment aided by quality analysis tools. Nucleic Acids Res 25, 4876-4882.

Yokota, A., Tamura, T., Nishii, T. \& Hasegawa, T. (1993). Kineococcus aurantiacus gen. nov., sp. nov., a new aerobic, Gram-positive, motile coccus with meso-diaminopimelic acid and arabinogalactan in the cell wall. Int J Syst Bacteriol 43, 52-57.

Zhi, X.-Y., Li, W.-J. \& Stackebrandt, E. (2009). An update of the structure and $16 \mathrm{~S}$ rRNA gene sequence-based definition of higher ranks of the class Actinobacteria, with the proposal of two new suborders and four new families and emended descriptions of the existing higher taxa. Int J Syst Evol Microbiol 59, 589-608. 